\title{
"PRACTICAL NECESSITY" OR "HIGHLY SOPHISTICATED OPPORTUNISM"? JUDICIAL REVIEW AND RATE REGULATION After atCO Gas and PIPELINES LTD. V. Alberta (ENERGY AND UTILTIES BOARD)
}

\section{ALICE WOOLI.EY}

\section{INTRODUCTION}

In ATCO Gas and Pipelines Lid. v. Alberla (Energy and Utilitics Board), the Supreme Court of Canada has considered for the first time in over 20 years the rate-making jurisdiction of the Alberta Energy and Utilities Board (AEUB). ' In a 4-3 decision, Bastarache J. held that the AEUB's jurisdiction to impose conditions "in the public interest," granted to it by s. 15(3) of the Alberta Energy and Utilities Board $A c t,{ }^{3}$ is subject to and constrained by the Court's identification of its legislative mandate. Section 15(3) provides, in essence, no greater authority to the AEUB than does the normal implied power of any regulatory agency to do that which is practically necessary to exercise its statutory authority. Further, and more specifically, Bastarache J. held that the utility has an uncompromised proprietary interest in assets used to serve utility ratepayers; that the utility bears the risk of any profit and loss associated with those assets; and that while the AEUB has the statutory authority to approve (or deny approval) of certain sales of utility assets, it has no authority to allocate any disposition of proceeds from such a sale to ratepayers.

This decision has important ramifications for judicial review and regulatory decisionmaking in general, and, for utility rate regulation and deregulation in particular. It suggests a reanimation in substance of the "jurisdictional question" approach to judicial review; that a general grant of "public interest" jurisdiction to a regulatory body does not in fact extend that body's jurisdiction; that the AEUB will need to reconsider its approach to asset disposition and cost of service rate-making; and that initiatives to introduce increased competition and deregulation must proceed on a different understanding of the relationship between ratepayers and the utility than previously existed. After providing a brief overview of the decision, this case comment will discuss these ramifications.

\section{II. $A T C O$ GAS}

In 2001, ATCO Gas and Pipelines Lid. (AGPL) applied to the $A$ EUB for approval of the disposition of land and buildings that it owned in downtown Calgary, and for approval of its proposed allocation to shareholders of the proceeds arising from that disposition. The AEUB granted approval of the disposition, ${ }^{4}$ finding that it would not result in harm to ratepayers in

Assistant Professor of Law. University of Calgary.

2006 SCC 4. [2006] I S.C.R. 140 [ATCO Gias].

Formerly, for ralte-making purposes, the Public Utilities Board. The most recent prior decision by the Courn was ATCO LAd. v. Calgany Power LAd., |1982| 2 S.C.R. 557 [Calgary Power].

R.S.A. 2000, c. A-17 [AEUB ACH].

AEUB Decision 2001-78: ATCO Gas and Pipelines L.Ad. Disposition of Calgary Srores Block and Distribution of Net Proceeds - Part I (24 October 2001), online: ALUB <wWw.eub.ca/docs' documents/decisions/2001/2001-78.pdP. 
terms of rates paid or the quality of service received. In a subsequent decision, the AEUB further determined, contrary to AGPL's request, that the proceeds should be allocated between shareholders and ratepayers. ${ }^{5}$ The AEUB allocated the proceeds not to protect ratepayers from any negative impact to rates or service (since it had found that there was none), but rather in pursuit of other rate-making principles such as decreasing the utility's incentive to engage in speculative asset transactions, and ensuring that the outcome reflected the ralepayers' sharing of financial risk with the utility.

This fact, which distinguished this sale of property from other disposition cases considered by the AEUB in recent years," focused the consideration of both the Alberta Court of Appeal and the Supreme Court on this question: does the AEUB have the jurisdiction to allocate proceeds from the sale of a utility asset even where the sale of that asset will have no negative impact on ratepayers' rates or service? The clear answer of a bare majority of the Supreme Court was "no."7

Justice Bastarache began his judgment by determining that the matter being considered by the Court was a jurisdictional question: it related to interpretation of the extent of the AEUB's powers and, despite the impact of other aspects of the pragmatic and functional analysis, was a matter with respect to which the AEUB was entitled to no deference. ${ }^{8}$ Further, Bastarache J. held that the AEUB's delineation of its jurisdiction was in error.

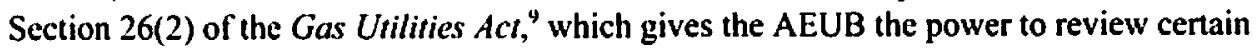
sales of utility assets, gives no conditioning power to the AEUB that would permit an allocation of proceds. ${ }^{10}$ The AEUB's general power pursuant to s. $15(3)$ of the $A E U B A C$ f to impose conditions in the public interest is "very wide and clastic" "I but, Bastarache J. somewhat surprisingly concluded, gives the AEUB no powers beyond those necessary for the exercise of its specific regulatory authority. Neither $i t$, nor the powers that arise from the regulator's implied authority to do that which is practically necessary for the discharge of its legislative mandate, are sufficient to allow the AEUB to allocate proceeds to ratepayers.

s AFUB Decision 2002-037: ATCO Gas and Pipleines L.Ad. Disposition of Calgary Srores Block and Distribution of Net Proceceds - Pomt 2 (21 March 2002), online: AEUB < www.cub.ca/docs/documents/ decisions/2012/2002-1037.pdt-. The distribution was in accordance with the "Trams $/$ lika Formula." in which sharcholders receive sale price/original cost multiplied by net book value. and ratepayers receive sale price/original cost mulliplied by depreciation paid.

- See, e.g. AlEUB Decision 2001 -46: ATCO Gas-North, A Division of ATCO Gas and Pipelines Lid. Sale of Certain Petroleum and Natural Gas Rights, Production and Gathering Assets. Storage Assets and Inventory (29 May 2001), online: AEUB <www.cub.ca/docs/documents/decisions/2001/2001-46.pdi> and AEUB Decision 2001-65 ATCO Gas-North. A Division of ATCO Gas and Pipelines Lid., Sale of Certain Petroleum and Nonural Gas Rights. Production and Guhlhering Assets. Storage Assets and Imentorn: Reasons for Decision 2001-46 (31 July 2001), online: AEUB <www.eub.cal docs/documents/decisions/2001/2001-65.pd/S [AFUB Decision 2001-65] (in which the Board considered $A T C O^{\prime}$ s application $(0$ dispose of its gas-producing assets in northem Alberta).

: In fact, as discussed below, the Court held that the AEUB3 does not have any authority to allocate procceds of a sale of capital assets, although it may be able to address harm to ratepayers arising from a proposed sale in other ways.

- $\quad A T C O$ Cas, supra note 1 at paras. 21-34.

$\checkmark \quad$ R.S.A. 2000, c. G-5 [GUA].

"1' $A T C O$ Cas, supra note 1 al para. 43.

11 $\quad$ bid. at para. 46. 
Justice Bastarache held that the allocation of proceeds from disposition of a utility asset - the rights to which rest without qualification with the utility ${ }^{\prime 2}$ - is not within the $A$ EUB's regulatory authority and is not practically necessary for it to accomplish its legislative objectives. To the contrary, such an allocation is an improper conliscation of the utility's property and constitutes retroactive rate-making. ${ }^{13}$ This is the case even where the allocation is limited to a return of the depreciation paid with respect to the asset, and recovered by the utility in the disposition. ${ }^{14}$ Any legitimate rate-making objectives of the AEUB, such as preventing speculation by the utility or preventing a negative impact on rates and service, can be appropriately addressed either through refusing approval of the disposition or through attaching conditions requiring asset replacement or financial reinvestment. ${ }^{\text {s }}$ Justice Bastarache also suggested that it may be possible, through the initiation of a general rate application, for the AEUB to give "due consideration to any new economic data anticipated as a result of the sale." 16 But in doing what it did here. Bastarache J. concluded that the Board made an improper and ultra vires attempt to confiscate the utility's property for customers:

In my view, allowing the Board to confiseale the net gain of the sale under the pretence of protecting ralepaying eustomers and acling in the "public interest" would be a serious misconception of the powers of the Board to approve a sale; to do so would completely disregard the economic rationale of rale selting. as I explained earlier in these neasons. Such an altempt by the Board to appropriate a ulility's excess net revenues for ratepayers would be highly sophisticated opportunism and would, in the end, simply increase the utility's capital costs (MacAvoy and Sidak, at p. 246). At the risk of repeating myself, a public utility is lirst and foremost a private business venture which has as its goal the making of profits. This is not contrary to the legislative scheme, even though the regulatory compact modifies the normal principles of economics with various restrictions explicilly provided for in the various enabling statutes. None of the three statutes applicable here provides the Beard with the power wo allocate the proceeds of a sale and therefore alfect the property interests of the public utility. ${ }^{17}$

In the alternative, Bastarache J. concluded for many of the same reasons that even if the AEUB had jurisdiction to impose this condition, it was unreasonable for it to have done so. ${ }^{18}$

In his dissenting judgment, Binnie J. provided a different characterization of what the AEUB had done, and held that its decision was both within its jurisdiction and was a reasonable exercise of that jurisdiction. Justice Binnic found that the Board did not confiscate AGPL's property at all, nor did it "allocate" proceeds to ratepayers. ${ }^{19}$ Rather, it simply made an adjustment to AGPL's prospective rates to reflect the economic impact of the transaction." This was a notional distribution of the bencfits arising from the disposition, but is best understood as a normal exercise of the AEUB's rate-making authority, and its discretionary power to act in pursuit of the public interest with respect to that authority. It is

Ibid. al, inter alia, paras, 68-69.

bid. at paras. 70-71.

This is implicit in the decision to allow ATCO's cross-appeal: ibid. at para. 87.

lbid. at para. 81 .

Ibid.

lbid. at para. 78.

lbid. at paras. $82+85$.

See, e.g., ibid. at para. 133.

lbid. at para. 130. 
true, Binnie J. conceded, that the AEUB did not make this decision through a general rate application, but this is simply a "procedural point"21 and has no substantive significance." And in any event, AGPL's proprietary rights to its assets are not the same as the proprietary rights of a company not subject to rate regulation; until it is removed from the utility's ratebase, all fluctuations in value of an asset held by a utility are absorbed by ratepayers, who pay a rate of return on the net book value of the assets. ${ }^{23}$ Finally, and after reviewing the extensive American jurisprudence and academic materials dealing with this issue, Binnie J. held that while it would have been perfectly reasonable for the AEUB to have reached a different decision and to have granted AGPL's application for allocation of proceeds to shareholders, it was also perfectly reasonable for it not to have done so:

\begin{abstract}
Perhaps not every regulator and not every jurisdiction would exereise the power in the same way, but the allocation of the gain on an asset ATCO sought to withdraw from the ratc base was a decision the Board was mandated to make. It is not for the Court to substitute its own view of what is "necessary in the public interest. ${ }^{24}$
\end{abstract}

\title{
III. JURISDICTIONAL QUESTIONS?
}

Prior to 1979, when the Supreme Court released Canadian Union of Public Employees Local 963 v. New Brunswick Liquor Corporation, ${ }^{25}$ the approach of the Supreme Court to judicial review was to characterize the nature of the question being decided by the tribunal and to review the decision based on that characterization. If the matter being considered was "preliminary" or "jurisdictional," the court would review the decision on a standard of correctness; if it was not, the court would not review the decision at all. ${ }^{26}$ Consideration of the nature of the decision-making body, or its competence relative to the court, was not generally relevant to the standard of review.

This approach was abandoned by the Supreme Court in the late 1970s, commencing with the CUPE decision. In that case, Dickson J. (as he then was) held that it is inappropriate to simply look at the nature of the question being decided in determining how the decision should be reviewed. Rather, the court must look as well at the nature of the specialization and expertise of the decision maker, and at the existence (or absence) of a privative clause, in determining the appropriate level of "judicial restraint" in reviewing the decision. ${ }^{28}$ This approach, later described by the Court as "pragmatic and functional" and evolving into a tripartite system of judicial review, ${ }^{24}$ arguably had as its motivating amimus removal of the arbitrariness and malleability of the preliminary question approach.

Ibid. at para. 96.

lbid. at para. 130.

Jbid. at para. 132.

lbid. al para. 148.

[1979] 2 S.C.R. 227 [CUPE].

Sece, e.g. Komo Construction Inc. v. Commission des Relution de Travail de Quebec. [1968] S.C.R. 172 and Bell v. Ontario (IItuman Rights Commission). [1971] S.C.R. 756.

CUPE, supra note 25 at 236.

Hoid. at 235-36.

Sct, e.g., Pushpemathan v. Canada (Minister of Citizenship and Immigration), [1998] I S.C.R. 982 [Pushpanathan] and Dr. Q. v. College of Physicians and Surgeons of British Columbia. 2003 SCC 19. [2003] I S.C.R. 226. 
In $A T C O$ Gas, the Court purported to follow the pragmatic and functional approach. That it did so should not however obscure the fact that, in essence, the Court's and, in particular, the majority's determination of the standard of review turned entirely on the nature of the question being considered. Where the question was characterized as jurisdictional, the AEUB's decision was reviewed for correctness; where it was characterized as an exercise of jurisdiction, it was reviewed for reasonableness. This is the case despite the fact that it is reasonable to argue, as Dickson J. did with respect to the Labour Relations Board in CUPE, that the interpretation of the appropriate scope of the AEUB's review of a proposed asset disposition, and in particular the extent to which it may impose conditions in the "public interest" in discharge of its legislative mandate, are matters of legislative interpretation that "would seem to lie logically at the heart of" the specialized jurisdiction confided to the Board." 30

But this position found no sympathy with a majority of the Court in ATCO Gas. ${ }^{31}$ It was the nature of the question, and not the expertise of the AEUB, its (admittedly qualifjed) privative clause or its broad legislative mandate - described earlier by the Supreme Court as being "a mandate of the widest proportions to safeguard the public interest" 32 - that determined the standard of review.

With respect, this approach is undesirable. It undermines the regulatory authority of bodies like the AEUB and gives insufficient respect to their expertise regarding these "jurisdictional" questions. Whatever its merits in other respects, ${ }^{33}$ Bastarache J.'s judgment rests on what is at best a gross oversimplification and, at worst an inaccuracy, in its assertion that utilities bear the risk associated with ownership of their assets. In fact, to say that they do bear this risk, and to regulate on that basis will, as discussed below, require significant changes to numerous aspects of the AEUB's broader regulatory governance of utility rates. The AEUB, with its extensive expertise (its jurisdiction over public utilities dates back for many decades through its predecessor, the Public Utilities Board), would never have made the error of stating that the "utility absorbs losses and gains, increases and decreases in the value of assets, based on economic conditions and occasional unexpected technical difficulties." 34 And if the AEUB had reversed course and made such a statement, it would certainly have appreciated its broader ramifications for utility rate-making. By failing to grant the AEUB any deference simply because of the "nature of the question" at issue, the Court failed to appreciate the pumerous ways (of which this is likely only one example) in which the AEUB simply understands better than do the courts the reality of the relationship between ratepayers and the utility, and also the potential ramifications of making changes to how that relationship is conceived.

CUPE. supra notc 25 at 236.

While Binnic J. also used a "correctness" standard for review of the Board's determination of its jurisdiction, he did not find the primary issue before the Court to be jurisdictional. Overall, his analysis was far more deferential to the Board's expertisc. Having said that, however, his willingness to allow the nature of the question to drive the standard of review analysis is also of concern for the reasons identified here.

Calgary Pou'er. sitpro note 2 at 576.

Bastarache J. makes a reasonable point that it is improper lor the Board to distribute procects outside of a general rate application and that to do so arguably constitutes retroactive rate-making. ATCO Gas, supro note l at para. 69. 
To put it simply, a majority of the Supreme Court misunderstood the way in which utility assets have been treated by regulatory bodies such as the AEUB in a scheme of cost of service rate-making. That misunderstanding, which is crucial to its analysis of the AEUB's jurisdiction, arises from its relative lack of expertise on utility matters. The whole point of the standard of review jurisprudence arising from the CUPE decision was to prevent the courts from making decisions where they do not have the expertise to do so properly. The ATCO Gas decision represents a regrettable departure from that approach.

It may be that the Supreme Court's approach to judicial review in the ATCO Gas decision represents an aberration, and that going forward the standard of review applied by the courts will not turn largely on the nature of the question to be decided. ${ }^{35}$ Certainly, the continued reliance by the Court (even in ATCO Gas) on the pragmatic and functional framework does leave courts with room in future cases to avoid this precedent. A court can emphasize, for example, the existence of a privative clause as warranting increased deference. It is also arguable, however, that so long as the Court continues in some cases to emphasize, as was done here, the nature of the question being considered. ${ }^{36}$ this alternative only increases the arbitrariness of the standard of review jurisprudence. The Court will not, as a general matter, defer to the expertise of regulatory bodies like the AEUB even where that expertise is highly relevant to the determination of jurisdiction. Instead, it will sometimes defer (where other aspects of the pragmatic and functional analysis say it should) and sometimes not (where, as in this case, it emphasizes primarily the nature of the question being considered); neither regulatory bodies, parties that appear before them, nor the general public will be able to predict with any reliability how the Court will approach the standard of review. Like equity traditionally applied, the outcome of the pragmatic and functional analysis will depend on the length of the chancellor's foot rather than on a rational and consistently applied analysis of the relative expertise of the decision maker with respect to the question being decided.

\section{Public InTEREST JURISDiction}

In his judgment, Bastarache J. held that the combined effect of s. 26 of the $G U A^{37}$ and s. 15(3) of the $A E U B A C t^{38}$ is that the "legislation is silent as to the Board's power to deal with sale proceeds." ${ }^{31}$ Thus, the only way for the AEUB to obtain power to allocate proceeds to ratepayers would be if that power could arise from these provisions when reviewed in their

35 There is, however, reason to believe that the "nature of the question" is becoming increasingly central to the application of the pragmatic and functional analysis. In Voice Construction Ltd. $v$. Construction and General Workers Union, Local 92. 2004 SCC 23, [2004] I S.C.R. 609, the Court held that legal questions will be subject to a less deferential standard unless they go to the heart of the decision maker's expertise. There are also several Supreme Court decisions in the last three years where the nature of the question has been largely determinative of the standard of review. See, e.g., Monsanto Canada litc. $v$. Ontario (Superintendent of Financial Senvices), 2004 SCC 54, [2004] 3 S.C.R. 152; Zenner v. Prince Edward Island College of Optometrists, 2005 SCC 77, [2005] 3 S.C.R. 645; Hilewiz v. Canada (.Minister of Citizenship and Immigration), 2005 SCC 57. [2005] 2 S.C.R. 706. There are also cases in which deference was applied despite the nature of the question. See, e.g., Alberta Union of Provincial Employees v. Lethbridge Commmity College. 2004 SCC 28, [2004] I S.C.R. 727.

Supra note 9.

Supra note 3.

ATCO Gos, supra note 1 at para. 47. 
statutory context, or if it could be implied as a "practical necessity for the regulatory body to accomplish the objects prescribed by the legislature."so

As earlier noted, Bastarache J. concluded that neither ss. 15(3) and 26 when viewed in their statutory context, nor the implied powers practically necessary for the accomplishment of the legislative objectives, cmpower the AEUB to allocate proceeds to ratepayers. What is significant here, however, is the extent to which the analysis of each of these two potential sources of authority coalesce. In both cases, the animating consideration for Bastarache $J$. appears to be that rate-making does not permit this type of appropriation of the utility's assets, and that the asserted power to do so is contrary to "the purpose and scheme of the legislation, the legislative intent and the relevant legal norms." the two possible sources of the AEUB's jurisdiction is substantially identical.

What this suggests is that courts may view a public interest conditioning power as doing no more for the jurisdiction of a regulatory body than does the implication of powers where such powers are practically necessary for the regulator's exercise of its legislative authority. This means that a legislature conferring jurisdiction on a regulatory body cannot rely on a public interest power to expand that body's jurisdiction. ${ }^{42}$ Such a power may do no more than provide a framework through which a court reviews action taken on the basis of allegedly implied powers, a kind of analysis the court would do in any event. The grant of a public interest power will provide a court with some indication of the breadth of mandate given to the regulatory body, but it may not substantively alter the range of actions the body can perform.

\section{ReVIEW OF DISPOSITION OF UTILITY ASSFTS}

The power given to the AEUB to approve material and/or unusual sales of utility assets is a standard power given to administrative agencies performing rate regulation. ${ }^{43}$ The general approach of the AEUB to the exercise of this power has been that it will permit the utility to dispose of the asset where doing so will result in "no harm" to ratepayers, taking into account both negative and positive impacts of the transaction, including the ability of the AEUB to offset harm arising from the transaction through an allocation of proceeds. ${ }^{44}$ That is, the AEUB has been willing to allow utilities to dispose of assets cven where prima facie the sale of the asset would negatively impact the utility's rates or service. ${ }^{\text {s5 }}$ The AEUB has done so because it could distribute some or all of the proceeds of disposition to customers to offset the economic consequences of that impact.

lbid. at para 48 .

Such general powets are granted to, imer alia, the Ontario Energy Board under the Ontario Energy' Board Act, 1998, S.O. 1998, c-15, ss. 52, 74(b) and the National Energy Board under the National Energy Board Aci, R.S.C. 1985, c. N-7, ss. 54(1), 58.35(1), 58.35(2), $119.09(1)$.

Sec, e.g., Ontario Energy Board Act, ibid., ss. 43, 86.

See AEUB Dicision 2000-41: TransAlia Unilities Corporation. Sale of Distribution Business (5 July 2000), online: AEUB <www.eub.ca/docs/documents/decisions/2000/2000-41.pd/> [AEUB Decision 2000-41] and AEUB Decision 2001-65, stupra note 6.

"[1]mpair the utility function or quality": ATCO Gas, supra note I at para. 44. 
ATCO Gas has two significant effects on the exercise of this power by the AEUB. First, the Court seems to suggest that the only assets that can be approved for sale are those which are no longer used and useful in utility service: "The provision can only be meant to ensure that the asset in question is indeed non-utility, so that its loss does not impair the utility function or quality." "That is, the test for disposition is "only" whether or not the asset is now a "non-utility" asset; if it is still a utility asset then, arguably, the sale should not be approved. This articulation of the test may imply that it is no longer appropriate for the AEUB to take into account positive impacts of the transaction in determining whether or not there is harm. If the asset is still a utility asset, then it is still a utility asset; the ameliorating effects of other factors (such as, for example, fostering competition in a deregulating market) $)^{47}$ are irrelevant to that determination.

Second, and more explicitly, by removing the AEUB's power to allocate proceeds, the Court clearly prevents the AEUB from using such an allocation to ameliorate the impact of a disposition. Even if, contrary to the first point, the AEUB can take into account positive impacts of the transaction, allocation of proceeds cannot be one such impact. If "the Board does not have the prerogative to decide on the distribution of the net gain from the sale of assets of a utility, ${ }^{48}$ then the Board clearly cannot decide on a distribution of the net gain in order to ameliorate the negative effect of the proposed transaction.

The consequence of these limitations on the AEUB's jurisdiction may be to reduce the flexibility of utility companies and of the AEUB with respect to asset transactions. For example, when AGPL disposed of its gas-producing assets (which it did at around the same time it sold the land and buildings at issue in this case), there was a clear and quantifiable harm to utility service that would flow to ratepayers from the transaction, measured in financial terms by the AEUB as ranging from $\$ 1,220,000$ for the least valuable property to $\$ 460,339,000$ for the most valuable property. ${ }^{49}$ That is, there was an impairment of "utility function or quality" from the sale of the properties, the economic impacts of which were in the hundreds of millions of dollars. The AEUB was ultimately willing to permit AGPL to dispose of the gas producing properties because an allocation of proceeds of disposition of the assets in a financial settlement with ratepayers was viewed as sufficient to remedy this impairment - to remove the economic harm that would otherwise result from the iransaction. ${ }^{50}$ However, and in accordance with the reasoning of the majority of the Court in $A T C O$ Gas, the AEUB could not reach this result today. The sale of the gas-producing properties was clearly found by the Board to impair the utility service; it was only because of the allocation of proceeds that the economic effects of the impairment were overcome and "no harm" was found to result from the transaction. Post-ATCO Gas, "the Board does not have the prerogative to decide on the distribution of the net gain from the sale of assets of a utility";' no allocation of proceeds to compensate for the impairment of utility function is

th Sid. [emphasis added].

47 This fictor was taken into account by the $\Lambda$ EUB in $\Lambda$ EUB Decision 2000-41, supmo note 44.

tK ATCO Gas, supra note 1 at para. 7.

iv AEUB Decision 2001-65, supro note 6 at 33.

- AEUIS Decision 2002-018: ATCO Gas - North. A Division of ATCO Gas amd Pipelines Lul. Distribulion of Proceeds from Sale of Producing Properties (21 February 2002), online: AEUB <www.cub.ca/docs/documents/decisions/2002/2002-018.pdf>.

$\quad$ ATCO Gias, supra nole 1 al para. 7. 
possible; the economic effects of the impairment to utility service cannot be rectified: and the "no harm" standard cannot be met. The utility would therefore be prevented from disposing of the assets."

It may be argued that the limited conditioning powers contemplated by Bastarache J., which would permit the AEUB to require asset replacement or financial re-investment by al utility, could remedy this problem. However, given the principles about ownership of the utility assets set out in Bastarache J.'s judgment and the relatively constrained nature of the conditioning powers he mentions, it is unlikely that this is the casc. If, for example, a "reinvestment of proceeds" is just a distribution of the net gain from the sale of the asset under another name, it may be overturned on judicial review - the AEUB cannot do covertly that which it cannot do overtly. Conversely, if the "reinvestment of proceeds" is not tantamount to an allocation, it is unlikely to be sufficient to remedy the harm, particularly in a case like that of the gas-producing properties where the negative economic impact of the sale was so great.

If the condition is for the purchase of a similar asset - a gas-producing property for example - this may be effective in rectifying harm but is likely to be as unattractive to the utility as a simple denial of approval. ${ }^{33}$ And, again, if it is not for a similar asset, it is not clear whether it would be sufficient to rectify the harm as required.

The power to give "due consideration to any new economic data anticipated as a result of the sale" in a general rate application is also not clearly of assistance. Again, it cannot be a different method for distributing the net gain on the sale of the asset to ratepayers. ${ }^{5 s}$ Nor is it clear that "consideration" of "new economic data" financial rectification of harm from the disposition, particularly where the harm may be measured in the hundreds of millions of dollars, as it was for the gas-producing properties.

Rather, it would appear that the AEUB's power is now largely limited to a simple approval or denial based on whether the asset in question can be properly characterized as "non-utility," without allowing for any ameliorating effect from sharing the proceeds of disposition of that asset with customers. ${ }^{57}$ In asset sale transactions more typical than that in $A T C O$ Gas $^{58}$ - where, for example, the asset proposed to be sold is still economically useful

I would also suggest that this problem could not be overeome through a settlentent between the utility and customers. Settements must be approved by the ALUB and the ALUB does not have jurisdietion to approve a settlement that it does not have jurisdiction to order.

For example, if the utility is selling the asset to adopt a different business model this condition would not permit it to do so.

S4 ATCO Gas, supra nole 1 at para. 81.

" That this is the case' is made clear by the fact that Bimnic J.'s judgment was based in significant part on his claracterizing the AFUB's decision in precisely this way. If consideration of new economic data could cover an allocation of proceeds. then there would have been no disagreenent betw een the majority and the dissent.

in $\quad A T C O$ Gas, supra note 1 at para. 81.

"I would assume that this standard would be different if the asset was going to remain in utility service but under different bwnership, as was the case with respect to TransAlta Uilities Corporation's sale of its distribution assets. See AEUB Decision 2000-41. supra note 44. 
in the provision of utility services - utility companies may well find this to be a difficult standard to meet.

\section{RATE-MAKING METhODOLOGY}

A utility's assets affect its rates primarily in two ways. First, the net book value of the assets make up a utility's rate base, on which it is entitled to earn a rate of return. ${ }^{59}$ Second, depreciation costs associated with the assets are included in the utility's revenue requirement - they are a cost recovered in rates.

In a normal rate case, the AEUB and other similar boards do nol review the existing rate base of a utility. They only consider proposed capital expenditures of the utility in order to determine whether those amounts are properly included in its rate base going forward. As a consequence, unless a utility applies to dispose of or acquire an asset, the AEUB does not direct its mind to the question of whether the assets included in the utility's rate base are still used and useful in utility service. If, for example. a pipeline owned by the utility and included in its rate base now has a net book value that exceeds its fair market value, and delivery could be economically provided by a third party through a contract for service ${ }^{60}$ (i.e., at a lower cost to customers), this would not normally be addressed by the AEUB in a general rate application. The AEUB would not require the utility to remove the pipeline from its rate base and obtain the services through outsourcing. ${ }^{61}$ Instead, the pipeline would simply be included in the utility's rate base as it had always been, and the utility would continue to earn a rate of return based on the pipeline's net book value. That is, the utility would earn a rate of return on the pipeline as if it was still used and useful in wility service, even though it was not because it could be cconomically replaced through outsourcing.

This approach has, of course, much to recommend it in terms of simplicity. It has also been conceptually justifiable because of the AEUB's and many other regulators' view of who bears the risk associated with an asset. The position of the AEUB has been that if an asset was properly included in the rate base at the outset, then it is ratepayers who properly bear the risks associated with changes in the value or usefulness of that asset, not the utility. ${ }^{62}$ As a consequence, it does not matter that the utility was potentially earning a rate of return on assets where those assets could be economically replaced, or where the asset had ceased to be necessary to provide utility services. In fact, allowing the utility to continue to earn a rate of return on the net book value of the assets has simply been a mechanism through which the ratepayers could shield the utility from negative risks associated with ownership of the asset, without the complexity of removing the asset from the utility's rate base and making a compensatory payment to the utility for its loss in value.

More accurately, the rate base determines the amount of financing that the utility requires. The utility's tinancing is made up of debt, preterred shares (in some cases), and common equity. The utility's rates then include interest on the debt, dividends on the preferred shares, and a rate of return on common equity - i.e., the "cost of capital" used to finance the utility's ussets. Utilities in Alberta not uncommonly use "Transportation by Others" arrangements in this way. In fact, it would not even tum its mind to the issue.

See ATCO Gas, stupra note 1 at para. 132. As discussed below, this is the case even if the asset ceases to be used at all, at which point it becomes a "stranded" cost and the utility will claim compensation from ratepayers for its loss of value at the point when it is removed from utility service. 
Justice Bastarache's reasons call this conceptual justification into question and suggest that the AEUB's traditional approach to a utility's rate base is no longer acceptable. The key concept underlying Bastarache J.'s judgment is his determination that the AEUB "wrongly assumed that ratepayers had acquired a proprietary interest" in the assets of the utility. ${ }^{63}$ Rather, the proprietary interest in the assets, and all risks associated with gains or losses in those assets, lie solely with the utility:

IS fhareholders are the ones solely alfected when the actual protits or losses of such a sale are realized; the mili!y absorbs losses and gains, increases and decreases in the value of assets, based on economic conditions and occasional unexpected technical ditliculties, but continuts to provide certainty in service both with regard to price and quality.

What this means is that the current regulatory approach, which places the risks of an asset's loss of usefulness with customers, cannot be justified. Instead, given that a utility bears the risk associated with its assets, it should be required to demonstrate on a continuing basis that the assets included in its rate base are used and useful - that they still provide utility service and/or that they could not be economically replaced with a new asset or with outsourcing. If the utility cannot demonstrate that an asset satisfies this standard, then that asset should be removed from its rate base, the services should be provided in another way, and no compensatory payment should be made to the utility for losses associated with the asset. If the risk lies with the utility, then it is a risk that the utility must be required to take; the utility should not be permitted simply to enjoy - to the exclusion of ratepayers - the benefits of an asset's appreciation in value while being shielded from any risks associated with a change in the asset's usefulness to customers. ${ }^{65}$

The calculation of depreciation expenses is also something that may warrant a different approach following the Court's decision. Depreciation is an unusual component of a utility's rates. It is not an expense that the utility incurs in a demonstrable sense - the utility cannot provide "receipts" of depreciation paid to a third party. It is, instead, an accounting concept used to ensure that assets are accurately represented on financial statements and that is treated as an actual expense for rate purposes, with its calculation dependent on the valuation reports of various experts. The abstractness of depreciation makes it one of the line items in a utility's revenue requirement with a material likelihood of being inaccurate. The allocation of proceeds upon the disposition of an asset was, if not a corrective for such errors, ${ }^{\text {, }}$ a disciplining of the utility's forecasting. If the utility grossly over-forecasts depreciation, this will increase the risk borne by ratepayers with respect to the asset but will also increase the amount that ratepayers receive upon disposition of the asset. In the absence of this discipline (which was always fairly weak given the infrequency of disposition), the AEUB should provide greater scrutiny of claimed depreciation expenses and should impose conservativism in forecasting those amounts. 


\section{Derfgulation and Competition}

As noted in Part VI, the presumption of most regulatory and other government bodies dealing with utilities was that, in the event the fair market value of a utility asset was lower than the net book value of the asset so that the utility asset could be economically replaced or was no longer used and useful, ratepayers should bear that cost - either through paying a rate of return on an amount in excess of the asset's fair market value, or through making a payment to the utility at the time the asset is removed from the utility's rate base. This is the concept of "stranded costs," which has been one of the more significant barriers to deregulatory initiatives, particularly in jurisdictions where electric utilities have numerous generating assets whose fair market value is well below their net book value. And even where the movement is not one of pure deregulation but is simply the introduction of greater competition, the possibility of stranded costs has been a barrier to regulatory change.

For example, in 2002, Nova Gas Transmission Ltd. (Nova) applied to construct a pipeline extension that would serve customers in the Fort Saskatchewan area currently served by ATCO Pipelines, a division of AGPL. The AEUB denied the application in part because of the rate implications for AGPL's ratepayers should AGPL's pipelines serving Fort Saskatchewan be "stranded or underutilized." If Nova had been allowed to construct its extension and AGPL's industrial customers in Fort Saskatchewan had switched to Nova, then AGPL would have had pipelines to Fort Saskatchewan that were not being used - which were "stranded" - and the economic loss associated with those stranded pipelines would be borne by AGPL's remaining ratepayers.

Subsequent to ATCO Gas, it is not clcar that this factor should or could be relevant to the AEUB's consideration. If the assets of a company facing increased competition or deregulation are "stranded or underutilized," then this is the utility's risk: "the utility absorbs losses and gains, increases and decreases in the value of assets, based on economic conditions." 68

This outcome will not necessarily benefit ratepayers in all circumstances. In deregulatory initiatives where the utility has significant "stranded" benefits - assets with fair market value in excess of net book value which are being taken out of the utility's rate base attempts have been made to preserve those benefits for ratepayers ${ }^{64}$ - an approach that may also be conceptually problematic lollowing ATCO Gas. If the assets belong to the utility, then in the event of a change in the regulatory regime such as the cessation of rate regulation of part of the utility service, the utility should be allowed simply to take its assets and use them in that new deregulated environment. The utility should not be required to share any of the benefits associated with its assets with parties who have no proprietary interest in them.

AEUB Decision 2002-058: Now Gas Trumsmissiom Lad. Application wo Construct Fort Saskatchewan Fxtension and Scotford, descephourg and Astotin Sales Meter Stations (2 July 2002), online: AIEUB <www.eub.co/docs/documents/decisions/2002/2002-058.pdrs at 20. This argument was clearly articulated in the submissions of ATCO Pipelines and endorsed by the Board (at 21 ). ATCO Gas, supra note 1 at para. 69.

en This is at least part of the rationale behind the development of the power purchase arrangements in Alberta. 
Further, the ultimate effect of such a change in approach might be to undermine the introduction of deregulation and competition. Utility companies have been relatively willing to participate in increased competition where they have at least the certainty of retaining the value of their original investment in utility assets. AGPL may have resisted the entry of Nova into the Fort Saskatchewan market, but at least it knew that it did not face the risk of losing the investment it had made in its pipelines to serve those customers. Were the retention of the value of those original investments no longer possible and companies such as AGPL faced a real risk of being uncompensated for stranded costs, they could hecome fiercely opposed to competitive initiatives in any circumstances where there might be stranded costs. While not definitive, such opposition is likely to be politically significant.

And on the flip side, customers are much more likely to resist regulatory change in cases of stranded benefits. Whatever its political popularity under the current approach, electricity deregulation would have been much more unpopular had the government, in accordance with the logic of Bastarache J.'s judgment, simply allowed the utilities to remove their extremely valuable generation assets from the rate base with no compensatory payment whatsocver to consumers.

\section{Conci.usion}

Whatever the merits of $A T C O$ Gas, it is in significant part wholly inconsistent with how regulatory agencies such as the AEUB, and even utility companies in other circumstances, have conceptualized the relationship between the utility and ratepayers with respect to asset risk. While the utilities have, not surprisingly, frequently attempted to retain proceeds upon disposition of an asset, they have not as a general matter viewed the risk associated with assets as resting entirely with their shareholders. An understanding that they do so, which Bastarache J. clearly articulates, must, absent legislative amendment, result in a significant change in the approach to rate regulation. Otherwise, rate regulation will be both incoherent and unfair, with utilities enjoying the upside of asset ownership while being wholly shielded from the downside.

One can also ask, however, whether this kind of sea-change in a long-standing approach to a regulatory problem is properly instigated by a court in a judicial review proceeding on a relatively narrow issue. As was recognized almost 30 years ago in $C U P E:^{70}$ the legislatures of Canada and the proyinces have exercised their authority to empower agencies like the AEUB to govern highly complex and technical regulatory problems such as utility rate regulation and deregulation. Those agencies do so by making interlocking, complex, and detailed decisions about the relationship between ratepayers and utilities (or labour and management or whomever is subject to the agency's jurisdiction) in a broad variety of areas and circumstances. It is highly questionable whether it is in the public interest, or consistent with the democratic legilimacy that underlies the excrcise of broadly defined powers granted by legislation, to have the courts, which appreciate little if anything about the intricacies of the regulatory scheme, substituting their judgment for that of the regulator. This is particularly the case when they do so in a way that resis on a fundamental misunderstanding 
of how the parties' relationship has proceeded and which necessitates a radical shift in the regulatory regime as a whole.

Judicial review requires (and has always required) a court to undertake a delicate and difficult balance between protecting the fairness and justness of the legal process, while also recognizing the democratic legitimacy of the exercise of power by regulatory bodies, particularly those that have been given "a mandate of the widest proportions to safeguard the public interest." ${ }^{\text {"11 }}$ In establishing this balance, the court should return to the first principles articulated by Dickson J. (as he then was) in CUPE and ensure that the nature of the decision does not obscure the nature of the decision maker and its qualifications to make that decision. Otherwise, the court will consistently find itself substituting its judgment for that of regulators in areas where it is poorly qualified to do so, and the result of that substitution will undermine the democratic values which a well-conceived regulatory regime protects. 